\title{
PENDIDIKAN KESEHATAN TERHADAP KEMAMPUAN REMAJA PUTERI DALAM PERAWATAN ORGAN REPRODUKSI
}

\author{
Surmiasih ${ }^{1}$, Noven Winarsi ${ }^{2}$, Wahidun ${ }^{3}$ \\ 1Program Studi Keperawatan, STIKes Aisyah Pringsewu Lampung. Email: surmiasih12@gmail.com \\ 2STIKes Karya Husada Kediri, Jawa Timur. \\ ${ }^{3}$ Sekolah Menengah Kejuruan Nurul Falah Tanggamus, Lampung
}

\section{ABSTRACT: THE EFFECTIVENESS OF REPRODUCTIVE HEALTH EDUCATION AMONG FEMALE ADOLESCENTS}

Background: The World Health Organization states that poor women's reproductive health problems have reached $33 \%$ of the total burden of diseases suffered by women in the world. In Indonesia alone $75 \%$ of women have experienced vaginal discharge at least once in their lives. In Lampung, it was recorded that the implementation of health promotion or health education about hygiene behavior regarding the care of reproductive organs in adolescents was $20.29 \%$ of teenagers doing good hygiene behavior.

Purpose: Knowing of the effectiveness of reproductive health education among female adolescents

Methods: This research is a type of quantitative research with quasi experimental design, one group pretest-post test design approach. The population is 124 female students. The sampling technique in this study uses the total population.

Results: There was an effect of health education on the ability of female adolescents in the care of reproductive organs, obtained p-value 0.001 .

Conclusion: expected to increase knowledge about reproductive health for adolescents and how to care for good reproductive organs so that adolescents avoid the adverse effects caused if they do not treat reproductive organs.

\section{Keywords : Reproductive health education, female, adolescents}

Pendahuluan: World Health Organization menyatakan masalah kesehatan reproduksi perempuan yang buruk telah mencapai $33 \%$ dari jumlah total beban penyakit yang diderita para perempuan di dunia. Di Indonesia sendiri $75 \%$ wanita pernah mengalami keputihan minimal satu kali dalam hidupnya. Di Lampung tercatat pelaksaan promosi kesehatan atau pendidikan kesehatan tentang perilaku hygiene tentang perawatan organ reproduksi pada remaja sebanyak 20,29\% remaja melakukan perilaku hygiene yang baik.

Tujuan: Diketahui adanya pengaruh pendidikan kesehatan terhadap kemampuan remaja puteri dalam perawatan organ reproduksi.

Metode: Penelitian ini merupakan jenis penelitian kuantitatif dengan desain quasi eksperimental design dengan pendekatan one group pretest-posttest. .Jumlah populasi adalah 124 siswi.Teknik pengambilan sampel dalam penelitian ini menggunakan total population.

Hasil: Ada pengaruh pendidikan kesehatan terhadap kemampuan remaja puteri dalam perawatan organ reproduksi, didapatkan $p$-value 0,001 .

Simpulan: Seluruh siswa dapat menambah pengetahuan tentang kesehatan reproduksi dan cara merawat organ reproduksi yang baik sehingga remaja terhindar dari efek buruk yang ditimbulkan jika mereka tidak merawat organ reproduksi.

\section{Kata kunci : Pendidikan kesehatan, kesehatan reproduksi, remaja, puteri}

\section{PENDAHULUAN}

Masa remaja disebut juga masa adolescence (tumbuh menjadi dewasa). Remaja merupakan masa transisi antara masa kanak-kanak menuju masa dewasa, dimana terjadi pacu tumbuh, timbul ciri-ciri seksual sekunder, tercapainya fertilitas, dan terjadi perubahan-perubahan psikologi dan kognitif.Tercapainya tumbuh kembang yang optimal tergantung pada potensi biologiknya (Soetjiningsih, 2007).

Beberapa masalah yang terjadi pada remaja salah satunya pada kesehatan reproduksinya.Banyak kasus remaja yang mengalami masalah pada organ reproduksinya seperti keputihan yang abnormal, mengalami infeksi menular seperti herpes, penyakit kulit 
lainnya dan tidak jarang ditemukan kasus remaja menderita carcinoma/kanker pada organ reproduksinya. Hal itu bisa disebabkan dari hygiene yang tidak baik pada organ reproduksi.Presepsi yang salah atau kurang menyebabkan perilaku kesehatan yang dilakukan remaja tidak maksimal dalam perawatan organ reproduksi (Purwaningrum, 2017).

Masalah kesehatan reproduksi perempuan yang buruk telah mencapai $33 \%$ dari jumlah total beban penyakit yang diderita para perempuan di dunia salah satunya adalah keputihan. Sekitar $75 \%$ wanita didunia pasti akan mengalami keputihan paling tidak sekali seumur hidup dan sebanyak $45 \%$ wanita mengalami keputihan dua kali atau lebih, sedangkan pada kaum wanita yang berada di Eropa angka keputihan sebesar 25\% dimana 40$50 \%$ akan mengalami kekambuhan. Angka prevalensi tahun 2014, 30-60\% wanita mengalami candidiasis, 20\%-40\% bacterial vaginosis dan 5\%15\% mengalami trichomoniasis (WHO, 2015). Di Indonesia sendiri $75 \%$ wanita pernah mengalami keputihan minimal satu kali dalam hidupnya dan setengah di antaranya mengalami keputihan sebanyak dua kali atau lebih. Hal ini berkaitan dengan cuaca yang lembab yang mempermudah wanita indonesia mengalami keputihan, dimana cuaca yang lembab ini dapat mempermudah berkembangnya infeksi jamur (Maghfiroh, 2010).

Berdasarkan estimasi pusat data dan informasi di Indonesia jumlah remaja di adalah 69.857.406 jiwa atau $18.11 \%$ dari jumlah perempuan. Sebanyak 43,3 juta jiwa remaja berusia 15-24 tahun berperilaku hygiene tidak sehat, yang merupakan salah satu penyebab terjadinya keputihan (Kementrian Kesehatan Republik Indonesia, 2015). Kejadian keputihan banyak disebabkan oleh bakteri kandidosis vulvovagenitis dikarenakan banyak perempuan yang tidak mengetahui membersihkan vaginanya, penyebab lainnya adalah vaginitis bacterial dan trichomonas vaginalis. Khususnya di Indonesia data yang ada dari wanita yang mengalami keputihan sulit untuk didapat, hal ini dapat di maklumi karena sedikit sekali wanita yang memeriksakan masalah alat reproduksinya Studi menunjukkan bahwa keputihan adalah yang paling serius didiagnosa pada kalangan wanita muda, sekitar $15-30 \%$ dari gejala perempuan yang mengunjungi dokter (Bubakar \& Amiruddin, 2012).

Data dari Badan Pusat Statistik (BPS) kota Bandar Lampung tahun 2015, jumlah remaja di
Provinsi Lampung mencapai 132.308 jiwa, yang harus kita waspadai perilaku kesehatan reproduksinya. Dalam Riset Kesehatan Dasar di Lampung tercatat pelaksaan promosi kesehatan atau pendidikan kesehatan tentang perilaku hygiene tentang perawatan organ reproduksi pada remaja sebanyak 20,29\% remaja melakukan perilaku hygiene yang baik. Remaja yang tidak melakukan perawatan organ reproduksi dikarenakan dari faktor pengetahuan yang kurang serta tidak adanya dukungan dan informasi dari orang tua dan tenaga kesehatan tentang pentingnya merawat organ reproduksi (Kementrian Kesehatan Republik Indonesia, 2013).

Kesehatan reproduksi didefinisikan sebagai keadaan sejahtera fisik, mental, dan sosial secara utuh (tidak semata-mata bebas dari penyakit atau kecacatan) dalam semua hal yang berkaitan dengan sistem reproduksi, serta fungsi dan prosesnya (Kumalsari, 2012). Kesehatan reproduksi sangat berkaitan dengan kebersihan organ. Organ reproduksi sangat penting dipelihara kebersihannya termasuk memilih air cebok, pembalut dan cara pemakaiannya, serta kekerapan menggantinya, kebersihan selama haid, serta pakaian dalam yang digunakan harus bersih. Menjaga kebersihan organ reproduksi adalah perawatan pribadi terhadap vagina yang harus dilakukan setiap perempuan agar vagina tetap bersih, normal, sehat, dan terhindar dari kemungkinan adanya penyakit (Wulandari, 2011).

Menjaga kebersihan organ kewanitaan dapat mencegah terjadinya infeksi bisa dilakukan dengan perawatan organ genetalia eksterna.Infeksi yang tidak ditangani secara tuntas dapat menyebabkan infeksi merembet ke rongga rahim, kemudian ke saluran telur dan sampai ke indung telur dan akhirnya ke rongga panggul.Buruknya perawatan organ genetalia eksterna dan kondisi yang lembab menyebabkan masalah.Infeksi yang diakibatkan oleh hygiene yang buruk sering terjadi pada wanita.Gejala seperti pruritus vulva, iritasi, inflamasi, gatal-gatal, rasa perih, kemerahan dapat dialami wanita (Baradero, 2006). Perilaku buruk dalam menjaga kebersihan genitalia, seperti mencucinya dengan air kotor, memakai pembilas secara berlebihan, menggunakan celana dalam yang tidak menyerap keringat, jarang mengganti celana dalam dapat berdampak menjadi pencetus timbulnya infeksi. Pengetahuan dan perilaku dalam menjaga kebersihan genitalia eksterna merupakan faktor penting dalam kehidupan sehari-hari (Ratna,

Surmiasih' Program Studi Keperawatan, STIKes Aisyah Pringsewu Lampung. Email: surmiasihı@gmail.com

Noven Winarsi ${ }^{2}$ STIKes Karya Husada Kediri, Jawa Timur.

Wahidun ${ }^{3}$ Sekolah Menengah Kejuruan Nurul Falah Tanggamus, Lampung 
2010). Perawatan organ reproduksi dapat dilakukan dengan cara bersihkan organ genetalia,gantilah celana dalam 2-3 kali sehari, gunakan celana dalam yang bersih dan berbahan katun, cuci tangan sebelum menyentuh organ genetalia,jangan pernah menggunakan handuk milik orang lain, Cukurlah rambut kemaluan maksimal 40 hari sekali, dan menjaga kebersihan diri pada organ reproduksi untuk menghindari kemungkinan buruk seperti tertularnya penyakit (Anurogo, \& Wulandari, 2011).

Studi pendahuluan di SMK Nurul Falah dengan wawancara kepada 10 siswi didapatkan 7 (70\%) siswi menyatakan belum pernah mendapatkan pendidikan kesehatan tentang perawatan organ reproduksi dan $3(30 \%)$ siswi pernah mendapatkan pendidikan kesehatan tentang perawatan organ reproduksi. Kemudian dari 10 siswi 8 diantaranya mengatakan pernah mengalami gangguan reproduksi berupa keputihan dan gatal-gatal dibagian vagina. Berdasarkan latar belakang tersebut penulis tertarik untuk meneliti tentang "Pengaruh pendidikan kesehatan terhadap kemampuan remaja puteri dalam perawatan organ reproduksi.

\section{METODE PENELITIAN}

Jenis penelitian ini adalah kuantitatif, penelitian kuantitatif adalah metode yang digunakan untuk menyelidiki objek yang dapat diukur dengan angka-angka, sehingga gejala-gejala yang diteliti dapat diteliti/diukur dengan menggunakan skalaskala, indeks-indeks atau tabel-tabel yang kesemuanya lebih banyak menggunakan ilmu pasti (Notoatmodjo, 2010). Penelitian ini menggunakan desain penelitian adalah quasi eksperimental design atau eksperimen semu dimana desain ini tidak mempunyai pembatasan yang ketat terhadap randomisasi, dan saat yang sama dapat mengkontrol ancaman-ancaman validitas. Pendekatan penelitian yang digunakan adalah one group pretest-posttest design. Artinya setiap subjek penelitian akan berikan pretest kemudian dilakukan perlakuan dan kembali diberikanposttest sehingga terlihat karakter subjek pada saat penelitian (Arikunto, 2010). Populasi Dalam penelitian ini yang dijadikan populasi adalah seluruh siswi kelas 2 dan 3 di SMK Nurul Falah dengan jumlah 124 siswi. Teknik pengambilan sampel dalam penelitian ini menggunakan total populasi.

Siswi di bagi menjadi 2 kelompok berdasarkan kelasnya, diberikan infomed consent/kesediaan menjadi responden. Selanjutnya peneliti memberikan pretest sebelum dilakukan pendidikan kesehatan untuk mengetahui kemampuan siswi/remaja dalam perawatan organ reproduksi. Setelah dilakukan pretest peneliti melakukan pendidikan kesehatan tentang perawatan organ reproduksi selama 40 menit, dengan menggunakan media power point, dan lealet. Selanjutnya setelah pemberian materi perawatan organ reproduksi peneliti memberikan postest untuk mengetahui tingkat pemahaman dalam melakukan perawatan organ reproduksi. Lembar posttest yang telah terkumpul selanjutnya dianalisa sesuai dengan uji yang telah ditentukan.

\section{HASIL}

Tabel 1. Kemampuan remaja sebelum diberikan pendidikan kesehatan $(\mathrm{N}=124)$

\begin{tabular}{lcc}
\hline $\begin{array}{l}\text { Kemampuan Remaja Sebelum } \\
\text { Pendidikan Kesehatan }\end{array}$ & Frekuensi & Persen(\%) \\
\hline Kurang Baik & 70 & 56.5 \\
Baik & 54 & 43.5 \\
Total & 124 & 100.0 \\
\hline
\end{tabular}

Berdasarkan tabel 1. diatas didapatkan bahwa perawatan organ repoduksi pada remaja sebelum pendidikan kesehatan sebesar $70(56,5 \%)$ kurang baik dan sebesar 54 (43,5\%) baik. 
Tabel 2. Kemampuan Remaja setelah diberikan pendidikan kesehatan $(\mathrm{N}=124)$

\begin{tabular}{lcc}
\hline $\begin{array}{l}\text { Kemampuan Remaja } \\
\text { Setelah Pendidikan } \\
\text { Kesehatan }\end{array}$ & Frekuensi & $\begin{array}{c}\text { Persen } \\
(\%)\end{array}$ \\
\hline Kurang Baik & 59 & 47.6 \\
Baik & 65 & 52.4 \\
Total & 124 & 100.0 \\
\hline
\end{tabular}

Berdasarkan tabel 2. diatas didapatkan bahwa perawatan organ repoduksi pada remaja setelah pendidikan kesehatan sebesar $59(47,6 \%)$ kurang baik dan sebesar $65(52,4 \%)$ baik.

Tabel 3. Pengaruh pendidikan kesehatan terhadap kemampuan remaja puteri dalam perawatan organ reproduksi $(\mathrm{N}=124)$

\begin{tabular}{|c|c|c|c|c|c|c|c|c|}
\hline \multirow{3}{*}{\multicolumn{2}{|c|}{$\begin{array}{l}\text { Kemampuan remaja } \\
\text { dalam perawatan } \\
\text { organ reproduksi }\end{array}$}} & \multicolumn{4}{|c|}{ Post } & \multirow{2}{*}{\multicolumn{2}{|c|}{ Total }} & \multirow{3}{*}{$p$-Value } \\
\hline & & \multicolumn{2}{|c|}{ Kurang Baik } & \multicolumn{2}{|c|}{ Baik } & & & \\
\hline & & $n$ & $\%$ & $\mathrm{n}$ & $\%$ & $\mathbf{N}$ & $\%$ & \\
\hline \multirow[t]{3}{*}{ Pre } & Kurang & & & & & & & \\
\hline & Baik & 59 & 47.6 & 11 & 8.9 & 70 & 56.5 & \\
\hline & Baik & 0 & 0.00 & 54 & 43.5 & 54 & 43.5 & 0.001 \\
\hline \multicolumn{2}{|c|}{ Total } & 59 & 47.6 & 65 & 52.4 & 124 & 100.0 & \\
\hline
\end{tabular}

Berdasarkan tabel 3. diatas didapatkan bahwa kemampuan remaja kurang baik sebelum dan sesudah diberikan pendidikan kesehatan sebesar $59(47,6 \%)$ dan kemampuan remaja baik sebelum dan sesudah diberikan pendidikan kesehatan sebesar 54 (43,5\%). Kemudian kemampuan remaja kurang baik sesudah diberikan pendidikan kesehatan namun baik sebelum diberikan pendidikan kesehatan sebesar $0(0 \%)$ dan kemampuan remaja baik sesudah diberikan pendidikan kesehatan namun kurang baik sebelum diberikan pendidikan kesehatan sebesar 11 $(8,9 \%)$. Hasil uji McNemer didapatkan p-value 0,001 dapat disimpulkan ada pengaruh pendidikan kesehatan terhadap kemampuan remaja puteri dalam perawatan organ reproduksi.

\section{PEMBAHASAN}

Berdasarkan hasil penelitian didapatkan bahwa perawatan organ repoduksi pada remaja sebelum pendidikan kesehatan sebesar $70(56,5 \%)$ kurang baik dan sebesar $54(43,5 \%)$ baik. Dapat disimpulkan bahwa sebagian besar remaja dengan perawatan organ repoduksi kurang baik. Hasil penelitian Siswati (2013) menyebutkan ada pengaruh penyampaian pendidikan kesehatan reproduksi oleh peer groub terhadap kemampuan perawatan daerah kewanitaan kepada remaja di dusun Tegalsari Sleman. Hasil penelitian didapatkan $54 \%$ responden memiliki kemampuan perawatan daerah kewanitaan kurang baik. Organ reproduksi yaitu suatu alat penting yang harus dan kita rawat kesehatannya. Perawatan Organ Reproduksi adalah cara melakukan perawatan terhadap organ reproduksi dilakukan oleh semua orang pria/wanita. Cara menjaga kesehatan organ reproduksi penting diketahui oleh semua orang tidak hanya wanita namun pria pun perlu mengetahui bagaimana cara menjaga dengan baik dan benar organ reproduksi yang dimilikinya, Selama ini jika ada yang menyebut organ reproduksi langsung pikiran masyarakat luas tertuju pada organ reproduksi wanita, padahal pria pun memiliki organ reproduksi yang juga harus dijaga dan dirawat. 
Menurut Pendapat Harahap (2003). Secara garis besar dapat faktor yang mempengaruhi kebersihan reproduksi, antara lain : faktorSosialEkonomi dan demografi (terutama kemiskinan,tingkat pendidikan yang rendah dan ketidak ketahuan tentang perkembangan seksual dan proses reproduksi, serta lokasi tempat tinggal yang terpencil). Faktor budaya dan Lingkungan (misalnya, praktek tradisional yang berdampak buruk pada kesehatan reproduksi, kepercayaan banyak anak banyak rezeki, informasi tentang fungsi reproduksi yang membingungkan anak dan remaja karena saling berlawanan satu dengan yang lain sebagainya). Faktor psikologis (dampak pada keretakkan orang tua pada remaja,depresi karena ketidakseimbangan hormonal, rasa tidak berharga wanita terhadap pria yang membeli kebebasan secara materi, dan lain sebagainya). Dan faktor biologis (cacat sejak lahir, cacat pada saluran reproduksi pasca penyakit menular seksual, dan lain sebagainya).

Baik dan buruknya perawatan organ reproduksi pada seseorang dapat dipengaruhi oleh beberapa faktor diantaranya pengetahuan, dari ketidak tahuan seseorang sangat menentukan perilaku mereka. Kemudian dipengaruhi juga oleh faktor sumber informasi dan dukungan orang tua. Sumber informasi bisa didapatkan dari media massa atau sosialisasi, jika banyak yang belum mendapatkan sosialisasi hal tersebut dapat mempengaruhi perilaku mereka dalam melakukan perawatan organ reproduksi. Dukungan orang tua yang baik untuk menerapkan perilaku bersih dan sehat terutama pada organ reproduksi juga berpengaruh terhadap kebiasaan mereka untuk melakukan perawatan.

Berdasarkan hasil penelitian didapatkan bahwa perawatan organ repoduksi pada remaja setelah pendidikan kesehatan sebesar $59(47,6 \%)$ kurang baik dan sebesar $65 \quad(52,4 \%)$ baik. Dapat disimpulkan bahwa sebagian besar remaja dengan perawatan organ repoduksi baik. Pendidikan kesehatan adalah proses untuk meningkatkan kemampuan masyarakat dalam memelihara dan meningkatkan kesehatan. Sedang dalam keperawatan, pendidikan kesehatan merupakan satu bentuk intervensi keperawatan yang mandiri untuk membantu klien baik individu, kelompok, maupun masyarakat dalam mengatasi masalah kesehatannya melalui kegiatan pembelajaran, yang didalamnya perawat berperan sebagai perawat pendidik (Notoatmodjo, 2012).
Penelitian Misgiyanti (2014) tentang Pengaruh penyuluhan kesehatan reproduksi terhadap perilaku menjaga organ kebersiihan alat reproduksi pada usia pubertas siswi kelas VIII di SMP N 1 Mirit Kabupaten Kebumen menyatakan bahwa pendidikan kesehatan sangat diperlukan untuk menanamkan nilai-nilai kesehatan bagi seseorang. Meningkatnya perilaku remaja dapat disebabkan karena bertambahnya pengetahuan remaja yang mencakup domain kognitif yang berpengaruh dalam membentuk tindakan seseorang. Cara menjaga kesehatan organ reproduksi penting diketahui oleh semua orang tidak hanya wanita namun pria pun perlu mengetahui bagaimana cara menjaga dengan baik dan benar organ reproduksi yang dimilikinya, Selama ini jika ada yang menyebut organ reproduksi langsung pikiran masyarakat luas tertuju pada organ reproduksi wanita, padahal pria pun memiliki organ reproduksi yang juga harus dijaga dan dirawat.Secara garis besar dapat faktor yang mempengaruhi kebersihan reproduksi, antara lain : faktor Sosial-Ekonomi dan demografi (terutama kemiskinan,tingkat pendidikan yang rendah dan ketidak ketahuan tentang perkembangan seksual dan proses reproduksi, serta lokasi tempat tinggal yang terpencil). Faktor budaya dan Lingkungan (misalnya, praktek tradisional yang berdampak buruk pada kesehatan reproduksi, kepercayaan banyak anak banyak rezeki, informasi tentang fungsi reproduksi yang membingungkan anak dan remaja karena saling berlawanan satu dengan yang lain sebagainya). Faktor psikologis (dampak pada keretakkan orang tua pada remaja,depresi karena ketidakseimbangan hormonal, rasa tidak berharga wanita terhadap pria yang membeli kebebasan secara materi, dan lain sebagainya). Dan faktor biologis (cacat sejak lahir, cacat pada saluran reproduksi pasca penyakit menular seksual, dan lain sebagainya) (Harahap, 2003).

Pendidikan kesehatan merupakan salah satu sarana untuk menambahkan sumber informasi dan pengetahuan seseorang. Dari ketidaktahuan seseorang dengan diberikan pendidikan kesehatan mereka lebih tahu dan dapat melakukan perubahan hidup sehat berdasarkan materi yang telah diberika serta merubah perilaku dalam melakukan perawatan organ reproduksi sehingga hasil penelitian sebagian besar perawatan organ reproduksi remaja dengan kategori baik.

Pengaruh pendidikan kesehatan terhadap kemampuan remaja puteri dalam perawatan organ

Surmiasih' Program Studi Keperawatan, STIKes Aisyah Pringsewu Lampung. Email: surmiasih12@gmail.com 
reproduksi, berdasarkan hasil pengolahan data didapatkan $p$-value 0,001 yang berarti ada pengaruh pendidikan kesehatanterhadap kemampuan remaja puteri dalam perawatan organ reproduksi. Hasil penelitian Sulistyoningtyas,,S (2016) dengan judul pengaruh penyuluhan kesehatan terhadap sikap remaja dalam merawat organ reproduksi menunjukkan ada pengaruh penyuluhan tentang kesehatan terhadap sikap merawat organreproduksi ditinjau dari akses media sosial. Penyuluhan dan akses media social mempengaruhi peningkatan sikap pada remaja puteri menjadi lebih baik dalam merawat organ reproduksi. Hal ini juga didukung oleh pendapat Walgito (2005) yang menjelaskan beberapa faktor yang dapat mempengaruhi sikap seseorang.

Sejalan dengan teori pendidikan kesehatan adalah proses untuk meningkatkan kemampuan masyarakat dalam memelihara dan meningkatkan kesehatan. Sedang dalam keperawatan, pendidikan kesehatan merupakan satu bentuk intervensi keperawatan yang mandiri untuk membantu klien baik individu, kelompok, maupun masyarakat dalam mengatasi masalah kesehatannya melalui kegiatan pembelajaran, yang didalamnya perawat berperan sebagai perawat pendidik (Notoatmodjo, 2012).Tujuan utama pendidikan kesehatan adalah agar orang mampu menerapkan masalah dan kebutuhan mereka sendiri, mampu memahami apa yg dapat mereka lakukan terhadap masalahnya, dengan sumber daya yg ada pada mereka ditambah dengan dukungan dari luar, dan mampu memutuskan kegiatan yg tepat guna untuk meningkatkan taraf hidup sehat dan kesejahteraan masyarakat (Mubarak, 2009). Organ Reproduksi adalah suatu alat penting yang harus dan kita rawat kesehatannya. Perawatan Organ Reproduksi adalah cara melakukan perawatan terhadap organ reproduksi dilakukan oleh semua orang pria/wanita. Ada berbagai cara yang bisa dilakukan untuk menjaga kesehatan organ reproduksi :memakai celana dalam dari katun, rajin mengganti celana dalam, mengeringkan organ reproduksi, tidak menggunakan obat pembersih wanita, rajin cuci tangan, mencuci tangan sehabis bab, membasuh organ reproduksi dengan benar, tidak menggaruk kemaluan, rajin mengganti pantyliner, menjaga kebersihan organ intim saat menstruasi, rajinlah mengganti pembalut, , rajin membersihkan badan, hindari gula dan kafein, hindari mengkonsumsi banyak alkohol, menjaga berat badan ideal (Prajati, \& Nawangsih, 2014).

Penelitian Hasnaeni (2018). mengatakan bahwa tingginya angka kejadian keputihan pada remaja putri. Upaya perawatan organ reproduksi yang sudah dilakukan, para responden rata-rata sudah melakukan perawatan organ reproduksi dengan baik, namun responden yang mengalami keputihan dapat dikarenakan perubahan hormone sebelum dan sesudah menstruasi, sekitar fase sekresi antara hari ke 10-16 siklus menstruasi. Berdasarkan hasil penelitian dapat disimpulkan bahwa setelah dilakukan pendidikan kesehatan sumber informasi dan peengetahuan responden menjadi lebih baik ditunjukan dari hasil kuesioner dengan perubahan perilaku remaja. Pendidikan kesehatan yang dilakukan peneliti dianggap penting dan dapat membuat mereka lebih mejaga kebersihan organ genetalia, melakukan perawatan dengan baik serta mengerti dampak yang akan ditimbulkan apabila tidak melakukan perawatan organ reproduksi. Dengan demikian agar banyak remaja mencapai kesehatan reproduksi yang baik sebaiknya sering dilakukan penyuluhan agar menambah wawasan remaja dalam segala bentuk kesehatan reproduksi baik perawatan organ reproduksi, masalah reproduksi dan sebagainya. Upaya yang perlu dilakukan oleh sekolah adalah dengan melakukan kerja sama lintas sektoral dengan tenaga kesehatan agar memberikan sosialisasi tentang kesehatan reproduksi, karena remaja merupakan generasi penerus respoduksi di masa depan. Sehingga dari dini remaja perlu mengerti pentingnya menjaga kesehatan reproduksi.

\section{SIMPULAN}

didapatkan perawatan organ repoduksi pada remaja sebelum pendidikan kesehatan sebesar 70 $(56,5 \%)$ kurang baik dan sebesar $54(43,5 \%)$ baik. Kemampuan remaja puteri dalam perawatan organ reproduksi setelah diberikan pendidikan kesehatan didapatkan perawatan organ repoduksi pada remaja setelah pendidikan kesehatan sebesar 59 $(47,6 \%)$ kurang baik dan sebesar $65(52,4 \%)$ baik. Ada pengaruh pendidikan kesehatanterhadap kemampuan remaja puteri dalam perawatan organ reproduksi didapatkan $p$-value $0,001(<0.05)$.

\section{SARAN}

Diharapkan hasil penelitian ini dapat meningkatkan pengetahuan tentang kesehatan

Surmiasih' Program Studi Keperawatan, STIKes Aisyah Pringsewu Lampung. Email: surmiasih12@gmail.com 
reproduksi bagi remaja dan cara perawatan organ reproduksi yang baik agar remaja terhindar dari dampak buruk yang ditimbulkan jika tidak melakukan perawatan organ reproduksi. Diharapkan hasil penelitian ini menjadi masukan bagi SMK untuk melakukan kerja sama lintas sektoral agar para siswa/i mendapatkan pendidikan kesehatan tentang kesehatan reproduksi dan dapat menerapkan dirumah agar terhidar dari dampak buruk akbibat kurangnya perawatan organ reproduksi. Penelitian ini dapat

\section{DAFTAR PUSTAKA}

Anurogo, D., \& Wulandari, A. (2011). Cara jitu mengatasi nyeri haid. Yogyakarta: CV Andi Offset.

Arikunto, S. (2010). Prosedur Penelitien Suatu Pendekatan Praktek, Ed. Revisi V. Jakarta: Rineka Cipta.

Bubakar, A.R, \& Amiruddin, M.D. (2012). Clinical aspects fluor albus of female and treatment. Indonesian J Dermatol Venerol, 1(1), 19-29.

Harahap, J. (2003). Kesehatan Reproduksi. Kesehatan Reproduksi.

Hasnaeni, H., \& Din, F. (2018). Hubungan perawatan organ reproduksi dengan kejadian keputihan pada mahasiswa DIII Kebidanan Tingkat 1 Kelas A Stikes Nani Hasanuddin Makassar. Jurnal IImiah Kesehatan Diagnosis, 12(3), 237-239.

Kementrian Kesehatan Republik Indonesia (2013). Riskesdas 2013. Jakarta: Badan Litbang Kesehatan.

Maghfiroh, K. (2010). Hubungan Pengetahuan tentang Keputihan dengan Penanganan Keputihan pada siswi Pondok Pesantren Darul Hasanah Kali Kondang Demak 2010. D III Kebidanan: Univeritas Muhammadiyah Semarang (UNIMUS). Karya Tulis IImiah. dijadikan data awal untuk melakukan penelitian selanjutnya tentang pengaruh pendidikan kesehatan tentang kesehatan reproduksi terhadap kemampuan remaja dalam perawatan organ reproduksi dengan menambahkan variabel lain seperti kemampuan remaja dalam melakukan personal hygiene atau vulva hygiene dan menggunakan metodologi penelitian yang berbeda seperti uji dengan menggunakan metode ekperimen.

Misgiyanti, (2014). Pengaruh penyuluhan kesehatan reproduksi terhadap perilaku menjaga organ kebersiihan alat reproduksi pada usia pubertas siswi kelas VIII di SMP N 1 Mirit Kabupaten Kebumen tahun 2014

Mubarak, W. I., \& Chayatin, N. (2009). IImu keperawatan komunitas pengantar dan teori. Jakarta: Salemba Medika.

Notoatmodjo, S. (2010). Metodologi Penelitian Kesehatan: Rineka Cipta Jakarta.

Notoatmodjo, S. (2012). Promosi kesehatan dan perilaku kesehatan. Jakarta: Rineka Cipta, 4562.ssertation, STIKes'Aisyiyah Yogyakarta).

Prajati, R. N., \& Nawangsih, U. H. E. (2014). Hubungan Pengetahuan Kesehatan Reproduksi Remaja Putri dengan Sikap Menghadapi Premenstrual Syndrome di SMP Mataram Kasihan Tahun 2014 (Doctoral dissertation, STIKES'Aisyiyah Yogyakarta).

Purwaningrum, A. E. (2017). Gambaran perilaku personal hygiene remaja putri kelas VIII dan IX Saat Menstruasi Di Smp N 1 Gamping Kabupaten Sleman.Ratna, D. P. (2010). Pentingnya menjaga organ kewanitaan. Jakarta: Indeks, 1-2.

Siswati, S., \& Isnaeni, Y. (2013). Pengaruh Penyampaian Pendidikan Kesehatan Reproduksi Oleh Peer Group terhadap Kemampuan Perawatan Daerah Kewanitaan pada Remaja di Dusun Tegalsari Tegaltirto Berbah Sleman (Doctoral dissertation, STIKES'Aisyiyah Yogyakarta). 
PENDIDIKAN KESEHATAN TERHADAP KEMAMPUAN REMAJA PUTERI DALAM PERAWATAN ORGAN REPRODUKSI

Soetijiningsih, P. (2007). Dr. SpA (K), IBCLC (penyunting) dalam Tumbuh Kembang Remaja dan Permasalahannya. Cet. 2. www.depkes.go.id/resources/download/.../profil -kesehatan-Indonesia-2015
Sulistyoningtyas, S. (2016). Pengaruh Penyuluhan Tentang Kesehatan Terhadap Sikap Remaja Dalam Merawat Organ Reproduksi. Jurnal Keperawatan Intan Husada, 3(2), 39. Walgito, B. (2005). Bimbingan dan konseling (Studi dan Karir). Yogyakarta: Andi

Walgito, B. (2005). Bimbingan dan konseling (Studi dan Karir). Yogyakarta: Andi 